\title{
加䞩ラットにおける組織トリグリセライドの量的，箕的変化
}

\author{
岩 垣 丞恒* 小林啓 三** 原田邦 彦** \\ 山田学** 酒井敏夫**
}

\section{QUANTITIVE AND QUALITATIVE STUDIES ON TISSUE TRIGLYCERIDE IN AGING OF RATS}

\author{
Suketsune Iwagaki, Keizo Kobayashi, Kunihiko Harada, \\ Manabu Yamada and Toshio SaKai
}

\begin{abstract}
A BSTRACT
Triglyceride contents of liver, heart muscle and skeletal muscles (rectus femoris, tibiaris anterior, soleus, plantaris and extensir digitrum longus) were determined on $1,3.5,14,18$ and 21 months-old rats, and especially on 14 and 21 months-old rats composition of triglyceride fatty acids was analyzed and interrelation of these triglyceride contents with aging of rats was studied quantitively and qualitatively. Following results were obtained:

1) Changs in liver and muscular triglyceride contents appeared on 14 months-old rats and were significant increase at 21 months-old rats.

2) Liver triglyceride content significantly decreased at 21 months-old $\operatorname{rats}(\mathrm{p}<0.05)$.

3) Triglyceride contents of tibiaris anterior and extensor digitrum longus muscles were mostly unchangeable through the aging of rats.

4) But triglyceride contents of soleus, rectus femoris and plantaris muscles in 21 months-old rats significantly increased $(\mathrm{p}<0.05)$ and the individual difference was great.

5) In composition of triglyceride fatty acids, increase of $\mathrm{C}_{18}, \mathrm{C}_{18-1}, \mathrm{C}_{18-2}$ and $\mathrm{C}_{18-3}$ was observed in epididymal adipose tissue, soleus and rectus femoris muscle on 21 months-old rats, but in extensor digitrum longus and tibiaris anterior muscles.

From these results, changes of tissue triglyceride contents with aging of rats are different in each tissue and increase of triglyceride content is present with qualitative changes in composition of triglyceride fatty acids, increase of long chain and unsaturated fatty acids, and organic specificity, which is related to the functional changes with aging of rats is considered.
\end{abstract}

(J. Physical Fitness Japan 1980, $29: 110 \sim 116$ )

\section{緒言}

脂質代謝における主たるエネルギー淙は脂肪組 織の triglycerideである。他の組織に遊離脂肪酸 を動員し，これらの組織との相互的代謝機構が成 ジしている。しかし，加秢現觉では，脂肪組織 の增加のみならず，血清，川下臟，悬格觔等にも triglyceride の增加が認められるようになる゙゚。
この睍泉は単なるエネルギー源としての增加とは 考えにくい。Harriman ${ }^{6}$ (は骨格筋脂質の多量の蓄 檟は病的変化の指愫となりうるとさえ述べ，生理 㙨能との関迎を考えさせられる。しかし，このよ うな胃采は名組織との相互的闑速によるものか, あるいはそれぞれの組織に㠺異的に涩められる现 彩であるかは十分解时されていない。本実験はこ の点に着目し，加榆に伴なう triglyceride の変化

* 東海大学体育学部運動生理 Department of Physical Recretion, School of Physical Education Tokai University. 
を量的並びに質的にとらえ，副睪丸脂肪組織，III 清, 心筋, 骨格筋, 肝臟 triglyceride の相互的関 係について検討した。

\section{実 験 方 法}

実験動物には生後 $1,3.5,14,18,21$ ケ月㳡命 のウィスター系雄性ラットを用いた。これらのラ ットを 18〜24 時間の絶食後, 断䫓, 脱血し，心 臓, 肝臓, 骨格筋 (大腿直筋, 前怪骨笳, 長指伸 筋，足底筋，ヒラメ筋）を摘出し， $4^{\circ} \mathrm{C}$ 以下の Krebs-Ringer 液中で腱, 結合組織, 脂肪組織を 十分に切除した。各組織を適当な大きさに切り, ガーゼで十分に水分を取り除き torsion balance で湿重量を計量した後, クロロホルム：メタノー

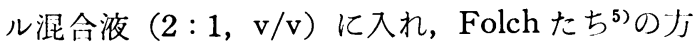
法にしたがって脂質を抽出した。これらの脂質を 薄莌クロマトグラフィー（展開剂；ヘプタン:石 油エーテル: ジェチルエーテル : 酢酸, $60: 20$ : $20: 1 \mathrm{v} / \mathrm{v} / \mathrm{v} / \mathrm{v}$ ) で分離し, $1 \%$ ウ素ークロロホル 么溶液を噴霧し, 各脂質分画の位置を確認した後 にそれぞれの脂質をかきとり，Kabara \& Chen の片法9を用いて triglyceride を定量した。

脂肪酸構成は，14並びに21ケ月齢ラットについ て検索した。同㥞の絶食条件下でペントバルビタ 一ルで麻酔後, 開胸し, 右心室から採血し, 直ち に副等丸脂肪組織と前述と同様の組織を摘出し, 同様の手技を用いて triglyceride と遊離脂肪酸 (FFA) を抽出した。これらの脂質を Stoffel たち 14)の方法に従って methylation し, ガスクロマト グラフィー（FID-163，日立製作所製）で分析し た。测定条件は温度 $190^{\circ} \mathrm{C}$ キァリアーガスは窒 素 (流速: $25 \mathrm{ml} / \mathrm{min}$ ), 空気 $1.5 \mathrm{~kg} / \mathrm{cm}^{2}$, 水絭 $25 \mathrm{ml} / \mathrm{min}$ である。カラムには $20 \%$ diethyleneglycol-succinate, chromosorb W AW (80-100 mesh) を充填したガラスカラム $(3 \mathrm{~m} \times 3 \phi)$ を用 いた。

\section{実 験 結 果}

各月齢ラットの心筋並びに朋蔵 triglyceride 含 有量を四 1 亿示した。各月柃 ラットの心竻 triglyceride は $1 \sim 2 \mu \mathrm{g} / \mathrm{mg}$ の範囲にあり，そのば らつきは少ない。肝蔵 triglyceride は $1,3.5$, 14 ケ月粭ラットともに $8 \sim 12 \mu \mathrm{g} / \mathrm{mg}$ の範囲にあ

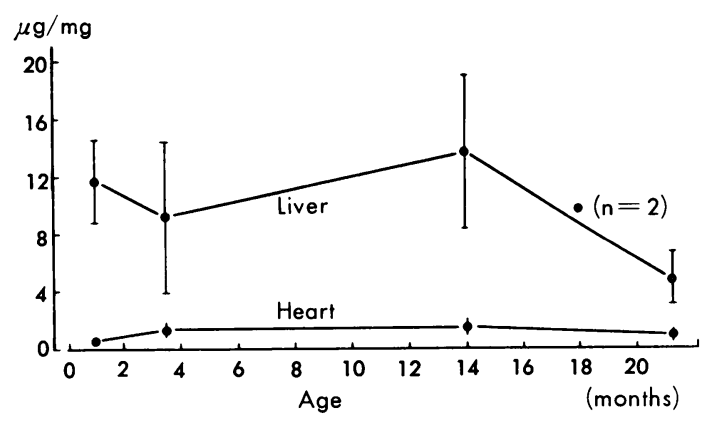

Fig. 1 Changes of triglyceride contents in liver and heart muscle with aging of rats. Each value is presented by mean \pm S.D.

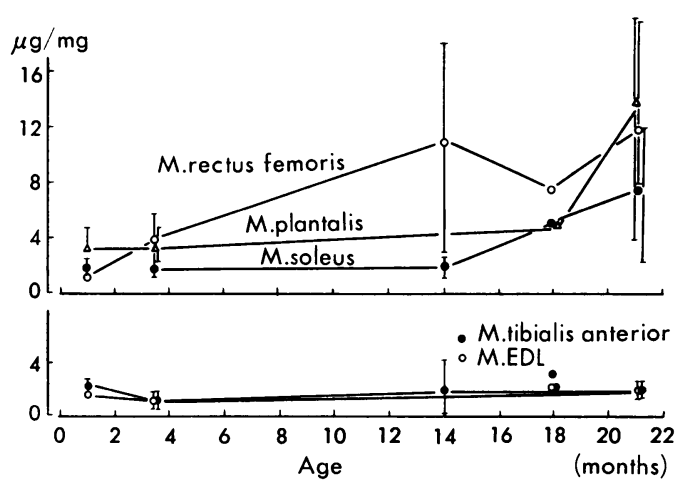

Fig. 2 Changes of muscular triglyceride contents with aging of rats. Upper figure; skeletal muscles which showed dominant increase of the triglyceride, lower figure ; skeletal muscles which were unchangeable through aging of rats.

ったがそそのばらつきが大きく，統計学的有意

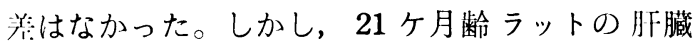
triglyceride は著しく低下し，統計学的に有意で あった（ $\mathrm{P}<0.05) 。$

各月齢ラットの骨格筋 triglyceride 含有量を図 2 に示した。骨格筋 triglyceride には各月秢でほ とんど変動のない筋肉（前怪骨筋, 長指伸筋）之 14あるいは 21 ケ月龄で著しい増加を示した筋肉 （大腿直筋，ヒラメ筋，足底筋）とが認められ， 21ケ月粭ラットでは，てれらの増加は統計学的に 有意であった $(\mathrm{P}<0.05)$ 。 triglyceride の増加 が認められた筋では 18 ケ月齢の值を参考にする と，その増加は14ケ月齢あたりから生じてくると 劣えられる。しかし，量的にかなりばらつきが大 きく，個体差も同將期飞生じているととを示唆し 

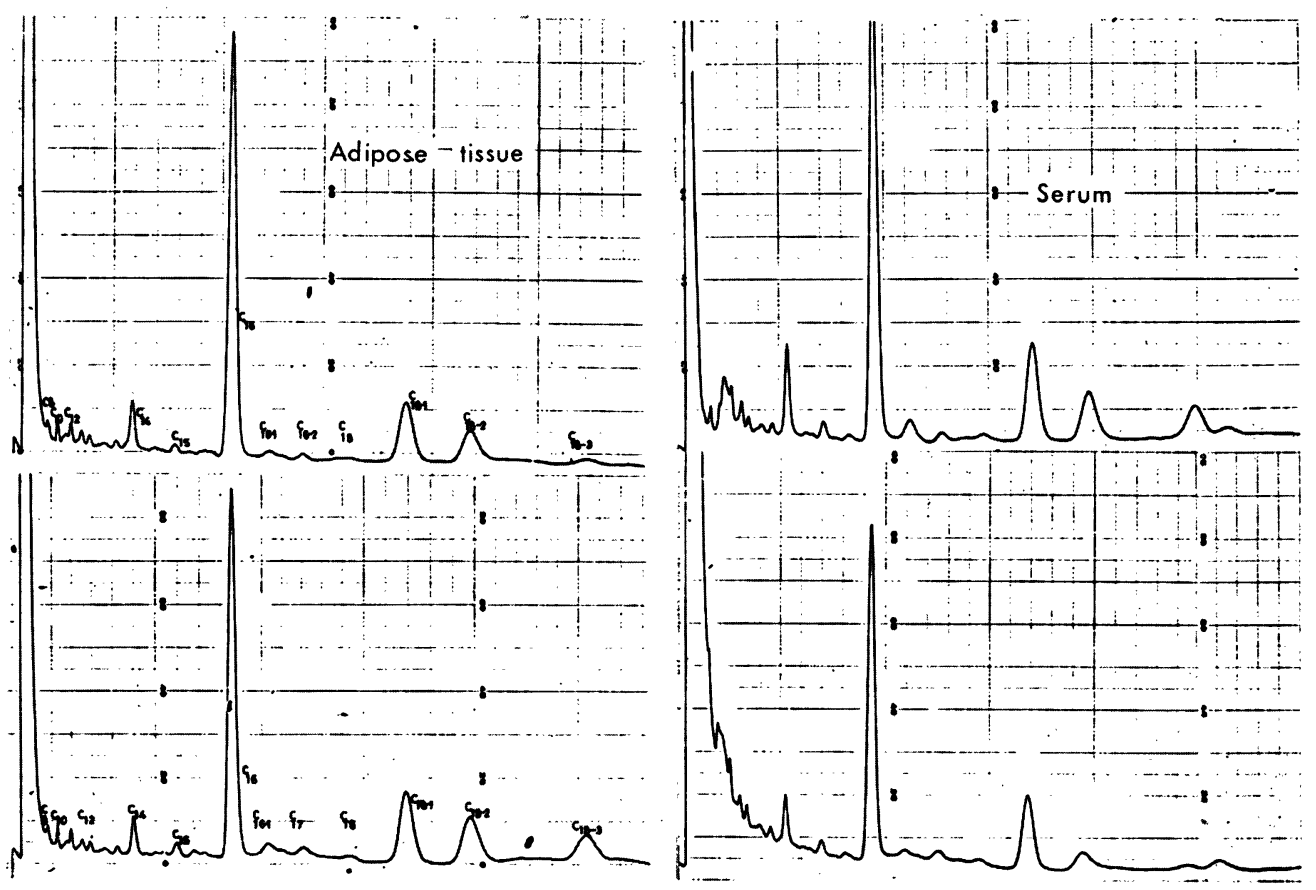

Fig. 3 Composition of free fatty acids in epididymal adipose tissue and serum. Upper figure ; 14 months-old rat, lower figure ; 21 months-old rat.

ている。

14並びに21ケ月齢ラットの副蛙丸脂肪組織とIIII 清との遊離脂肪酸分画を図 3 に示した。各月齢亏 ットの副箤丸脂肪組織では $\mathrm{C}_{14}, \mathrm{C}_{16}, \mathrm{C}_{18-1}, \mathrm{C}_{18-}$ ${ }_{2}, \mathrm{C}_{18-3}$ が顕著に認められ, 各月路間で遊離脂肪 酸分画に差は認められなかった。血清遊離脂肪酸 分画は副等丸脂肪組織 の遊離脂肪酸分画之類似 し，14ケ月齢と21ケ月齢ラットとの間には質的差 は認められなかった。これらの結果は副䔂丸脂肪 組織から遊離する脂肪酸分画に加齫による変動は なく，血清遊離脂肪酸分画に直接的に関連してい る事を示している。

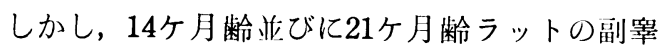
丸脂肪の triglyceride 構成脂肪酸では明らかな差 異が認められた（図 4 ）。14 ケ月粭ラットの triglyceride 構成脂肪酸に対し，21 ケ月齡ラットで は $\mathrm{C}_{10}, \mathrm{C}_{12}$ が低下し, 逆に $\mathrm{C}_{18}, \mathrm{C}_{18-1}, \mathrm{C}_{18-2}$, $\mathrm{C}_{18-3}$ が著しく多くなっている。したがって, 図 3 及び図 4 の結果から, 副等丸脂肪組織の triglyceride 構成脂肪酸に加秢变動が生じているに あかかわらず, 脂肪組織並びに血清遊離脂肪酸分 画にはその影響が生じていないととがわかる。

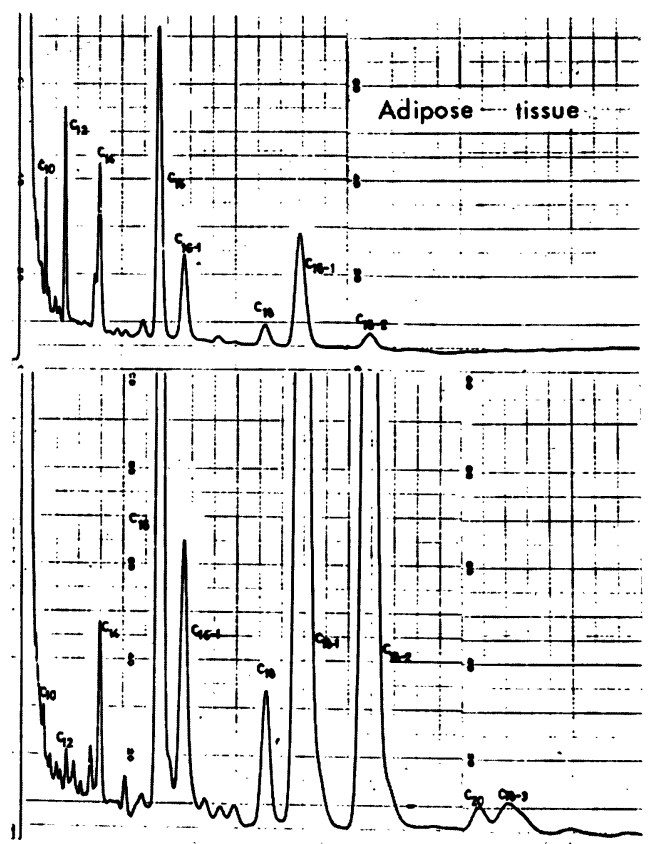

Fig. 4 Composition of triglyceride fatty acids in epididymal adipose tissue. Upper figure; 14 months-old rat, lower figure;21 monthsold rat. 

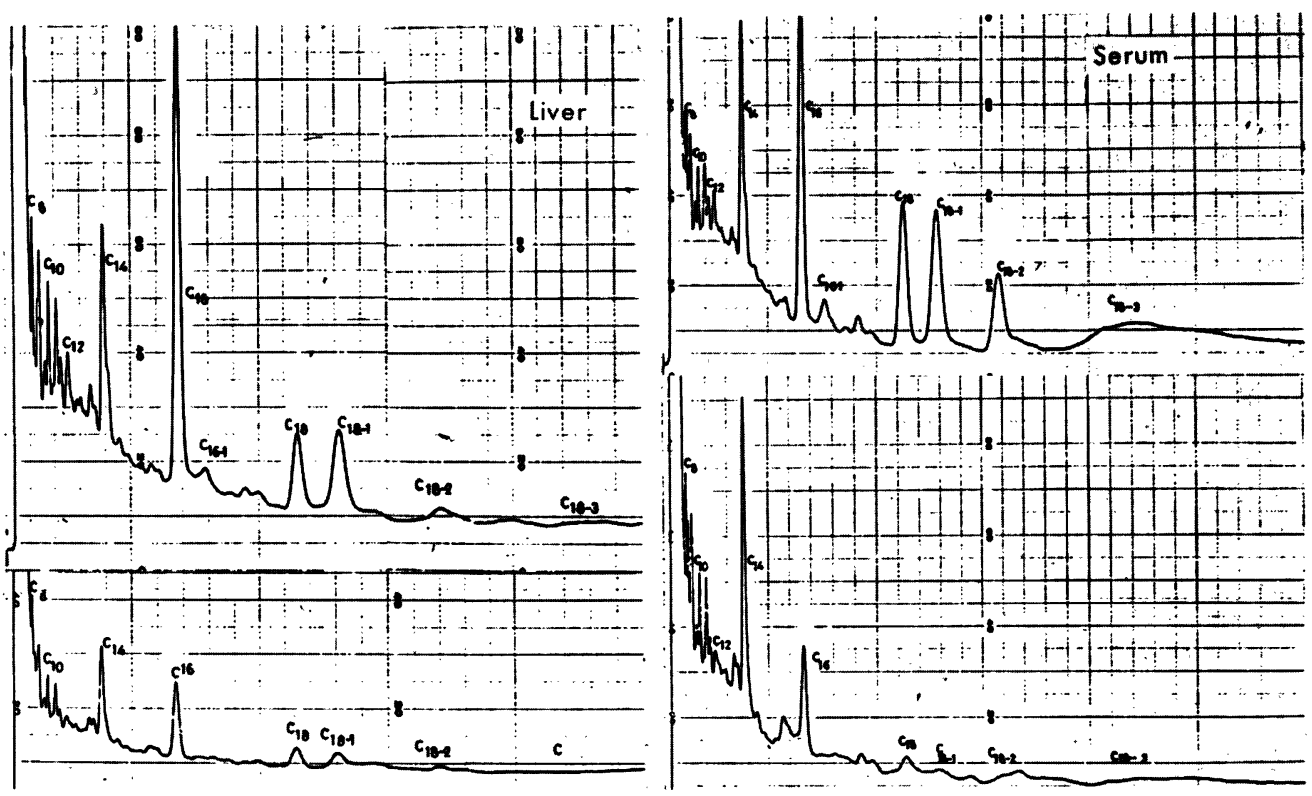

Fig. 5 Composition of triglyceride fatty acids in liver and serum. Upper figure ; 14 months-old rat, lower figure; 21 months-old rat.
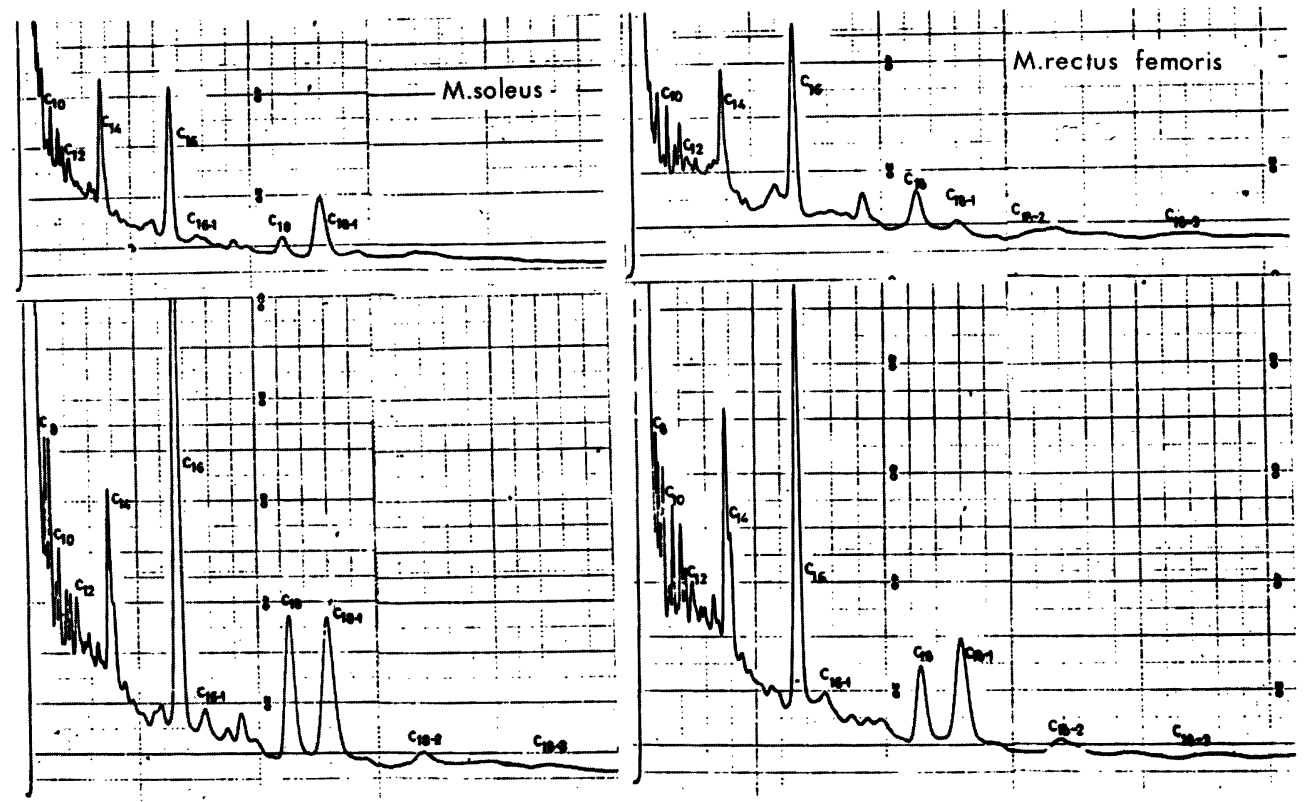

Fig. 6 Composition of triglyceride fatty acids in soleus and rectus femoris muscles. Upper figure ; 14 months-old rat, lower figure ; 21 months-old rat.

肝㖑並びに血清 triglyceride の構成脂肪酸分画 を図 5 に示した。14ケ月秢ラットでは朋蔵並びに IIII清 triglyceride の構成脂肪酸は類似し，血清 triglyceride が朋臓で 合成される lipoprotein に 由来することを示している。しかし，21ケ月柃ラ
ットではこれらの構成脂肪酸分画で特に $\mathrm{C}_{16}$ の低 下が認められた。

triglyceride の増加が認められなかった前怪骨 筋並びに長指伸筋について，その triglyceride 構 成脂肪酸分画を図 6 に示した。前怪骨筋では各月 

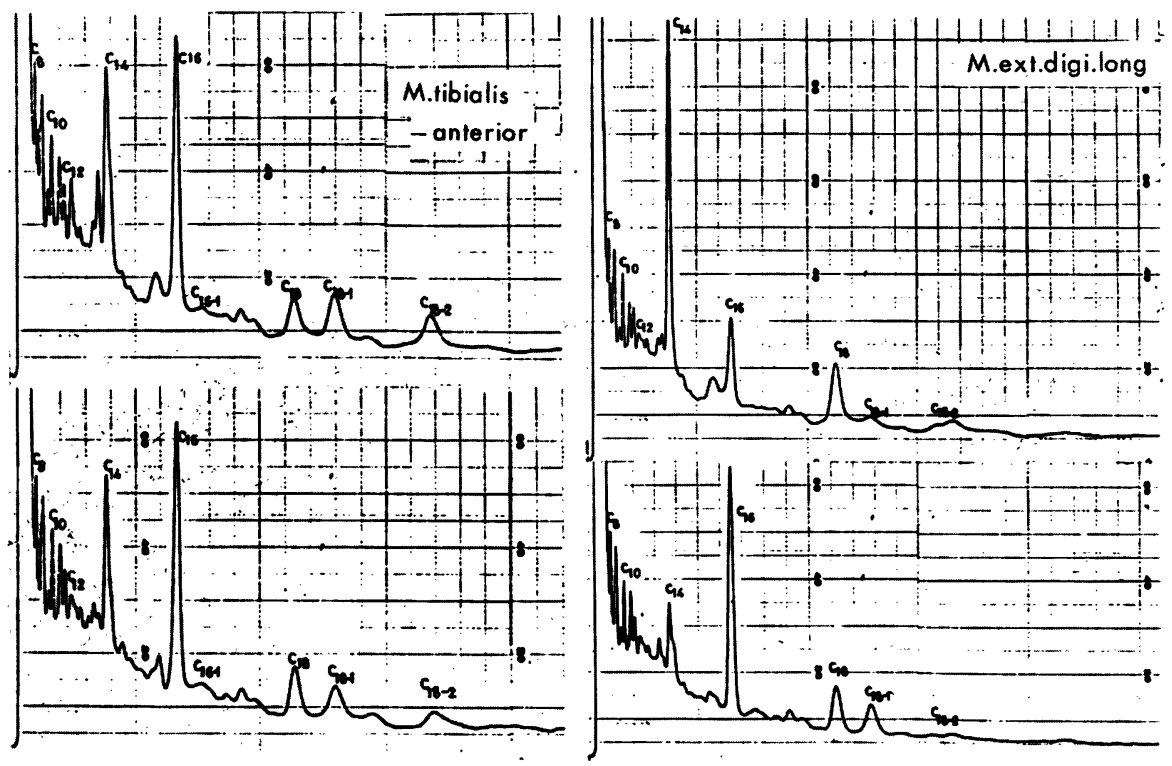

Fig. 7 Composition of triglyceride fatty acids in soleus and extensor digitorum longus (EDL) muscles. Upper figure ; 14 months-old rat, lower figure ; 21 months-old rat,

秢ラットの間に差はほとんど認められなかった。 長指伸筋ではその構成脂肪酸分画で $\mathrm{C}_{14}$ の低下, $\mathrm{C}_{16}$ の増加が認められたが, $\mathrm{C}_{18}, \mathrm{C}_{18-1}, \mathrm{C}_{18-2}$ 等には変動が認められない。

Triglyceride の増加が著しく認められたヒラメ 筋, 大腿直筇について, その triglyceride 構成脂 肪酸分画を図 7 に示した。14 ケ月齿ラットに比 べ, 21ケ月秢ラットではその分画上に $\mathrm{C}_{16}, \mathrm{C}_{18}$, $\mathrm{C}_{18-1}$ の増加が認められ, 図 6 の結果とは明かに 異っていた。図 2，6，7 の絬果から加秢による骨 格筋 Triglycerideの增加の背景には単に量的な变 化ばかりではなく，質的にも晎っていることがわ かる。

\section{実験成績に対する考察}

組織 triglyceride は細胞閒隙, 細胞膜, 細胞内 の triglyceride の総和である。練胞間隙での triglycerideの増減は血液中 lipoprotein 並びに chylomicrone の特性からみても考えにくいので，そ の大部分は細胞膜並びに細胞内の triglyceride が この変動に関係している。

佐藤 ${ }^{12}$ はガマ骨格笳紏胞膜構成脂質のうち15〜 20\%が triglyceride であると報告している。Peter \& Fiehen ${ }^{11)}$ はラットの赤筋並びに白筋について 細胞膜, 筋小胞体, ミトコンドリアの構成脂質を
比较し，細胞膜に最も多くの中性脂質が存在して いると述べている。た, Nagai たち(10) は生後 1 〜21ケ月秢ラットの心筋では組織中総 phospholipids の増加に組織中 triglyceride の增加が伴なう ことを示した。これらの報告から細胞膜 triglyceride 屯組織中 triglyceride の变動に関連してい るととが考えられる。

しかし, 運動8) やニコチン酸投与2) による組織 triglyceride の減少, corn oil ${ }^{7)} や$ ethanol 投与.1) で観察される組織 triglyceride の增加などは短時 閒で生じ，乙れらの変動には細胞内 triglyceride が最も大きな役制をもっていると考えられる。 Hayashida \& Schmalbruch は7)ラットに corn oil を与え 2 時間後に mitochondria の多い筋線維 (Type C) で細胞内の脂肪滴の直径が 20\%增大し たと報告し，速かに triglyceride として ester 化 されている事を示した。また, Harriman (は) ヒ 卜骨格筋細胞の脂肪滴は正常な場合, 值径が 0.5 $\mu \mathrm{m}$ 以下でその数も少ないが, 病的な状態では直 径が $1.5 \mu \mathrm{m}$ にも增加し，その後も多くなるとい う。Stein \& Stein $^{13)}$ はラットの心臟淮流液に oleic acid- ${ }^{3} \mathrm{H}$ を加え, ラジオオートグラフによ る分析を行なった結果, 潅流初期には筋小胞体, mitochondria $に$ radio activity が認められるが, その後は脂肪滴中に多くなるという ester 化の機 
構を報告した。これらの報告は細胞内 triglyceride の変動を中心的に考えてもよい事を示唆してい る。

14ケ月柃と21ケ月齢ラットを比洨すると, 組織 triglyceride の変動には，著しい増加を示した筋 (ヒラメ筇, 大腿南筋, 足底筋), 全く変化のなか った筋（前怪骨筋，長指伸筋，心筋），減少した 朋臟が垫められた。これらの結果は老化における triglyceride 含有量の増加はそれぞれの組織によ って異なり, 全ての臟器, 組織に統一的に認めら れる現㿝ではない束を示している。Triglyceride の增加が垫められた組織では，Dixon")の考えオ を参考にするとそれらの絒胞内で micellar fatt か ら globular fatt への変化が考えられ, “deposition”からいわゆる “accumulation” への移行む 考えられる。本実験絬果（図2）はこの量が著し く, 21 ケ月秢ラットのこれらの筋では特にその triglyceride 構成脂肪酸分画に $\mathrm{C}_{18}, \mathrm{C}_{18-1}, \mathrm{C}_{18-2}$ の增加があり,質的にも異ってくることを示した。 この "accumulation" の背景には phospholipids 並びに cholesterolと酵素活性との関連性が弱まる 事が考えられる。一少, Stein \& Stein ${ }^{13)}$ は oleic acid- ${ }^{3} \mathrm{H}$ を用いて筋小胞体 triglyceride と mitochondria triglyceride との比を経時的に観察し, 5 分間に3.5から1.5へ減少すると報告した。この ような質的変化は筋小胞体との関进にある事を示 す。乙の質的変化の現象は副殬丸脂肪組織にも認 められ，14と21ケ月榆ラットを比較すると21ケ月 梌ラットでは $\mathrm{C}_{16}, \mathrm{C}_{18}, \mathrm{C}_{18-1} \mathrm{C}_{18-2}, \mathrm{C}_{18-3}$ に增 加があった(図 4 )。しかし，血清並びに副等丸脂 肪組織の遊離脂肪酸分画にはこれらの分西西の増加 が認められない（図 3 )。乙の事柄も前述の脂肪 㵜における構成変化とを支持する結果であろう。

しかし，同じ骨格筋でも $1 ， 3.5 ， 14 ， 21$ ケ月 歯を通じて全く triglyceride 含有量に変動のない 筋（前怪骨筋，長指伸筋）もあり，これらの筋で は triglyceride 構成脂肪酸分画にも変化がなかっ た。

骨格筋 triglyceride 含有量並びにその構成脂肪 酸分画の違いには, 赤筋並びに白筋による差も考 えられるが，明確に区別できるわけではなく，ま た lipoprotein lipase 活性 ${ }^{15)}$ の差異を考虑すると 考えにくい結果である。したがって，てれらの変
化はむしろ老秢化に伴う筋の機能低下に関連して いるように思われる。

朋臟 triglycerideは21ケ月齢ラットで有意の低 下が認められ，Carlsonたぢ)の結果とは異なっ ている。この养異はラットの月粭差によると考え られる。本実験において, その構成脂肪酸分画は $\mathrm{C}_{16}$ の低下が著しく，血清 triglyceride の構成脂 肪酸分两にも同㥞のパターンが得られた。これら の結果は肝蔵での lipoprotein 合成に質的な変化 が生じている事を示し, 肝臓 triglyceride の減少 屯老齢化に伴なう機能低下であると考えられる。 この現像は血清 lipoprotein 中の triglyceride 構 成脂肪酸分画に出現しているので，その分再変動 が老齢化を推察する 1 つ指標となり得ることを 示す。

\section{摘要}

加秢ラットにおける triglyceride の增加を，心 筋, 朋臟, I监清, 骨格筋 (大腿直筋, 前怪骨胼, 長指伸筋, 足底筋, ヒラメ筋), 副䔂丸脂肪組織 について量的並びに所的に検討し, 相互関係を追 究した。

1）各組織の triglyceride 含有量の変動はおよ そ14ケ月粭以後のラットに認められた。

2) 心筋, 前怪骨笳, 長指伸筋の triglyceride 含有量は $1,3.5,14,21$ ケ月梌ラットではほと んど変動が認められなかった。

3）朋臓 triglyceride は21ケ月榆ラットで著し く低下し, 統計学的有意着 $(\mathrm{P}<0.05)$ が認めら れた。

4) 大腿直筋, 足底筋, ヒラメ筋の triglyceride 含有量は 14 ケ月柃あたりから徐々に增加し，21ケ 月榆ラットでは統計学的に有意 $(\mathrm{P}<0.05)$ な増 加となった。

5）14ケ月柃並びに21ケ月齢ラットの各組織の triglyceride 構成脂肪酸分画を比較すると, 21 ケ 月柃ラットでは $\mathrm{C}_{18}, \mathrm{C}_{18-1}, \mathrm{C}_{18-2}$ の增加が認め られ，血清中遊離脂肪酸分四门の反映は認められ なかった。また, triglyceride 含有量の增加が認 められた骨格筋（大腿直筋，ヒラメ筋）でも同様 の変化が認められた。

以上の絬果から，加柃ラットにおける triglyceride の変動はそれぞれの組織により異なり， 
triglyceride の增減が著しい組織ではその構成脂 肪酸にも質的な差が生じるととが示唆された。 （觉付 昭和55年 2 月 6 月）

\section{文献}

1) Baraona, E. and Lieber, C.S. (1979): Effects of ethanol on lipid metabolism. J. Lipid Res. 20, 289-315.

2) Carlson, L.A., Fröberg, S.O. and Nye, E.R. (1966) : Acute effects of nicotinic acid on plasma, liver, heart muscle lipids. Acta Med. Scand. 180, 571-579.

3) Carlson, L.A., Fröberg, S.O. and Nye, E.R. (1968) : Effect of age on blood and tissue lipid levels in the male rats. Gerontrogia 14, 65-79.

4) Dixson, K.C. (1958) : Fatty deposition : A disorder of the cell. Q.J. Exp. Physiol. 43, 139-159.

5) Folch, J.R., Lees, M. and Sloane Stanley, G.H. (1957) : A simple method for the isolation and purification of total lipids from animal tissues. J. Biol. Chem. 226, 497-509.

6) Harriman, D.G.F.(1973): The fine structure of intramuscular lipids in skeletal muscle. In : Basic Research in Myology, I. Ed. by Kakulas. Amsterdam. Excerpta Medica, 177-182.

7) Hayashida, Y. und Schmalbruch, H. (1972): Zur Grobe der Fettpartikle in mitochondrienreichen skelett muskel fasern de Ratte in Abhaging-keit von der Nahrungsaufnahme. Z. Zellforsch. 127, 374-381.
8) Issektz, B.Jr., Miller, H.I., Paule, P. and Rodahl, K. (1964) : Source of fat oxidation in exercising dogs. Am. J. Physiol. 207, 814-817.

9) Kabara, J.J. and Chen, J.S. (1976) : Microdetermination of lipid classes after thin-layer chromatography. Analyt. Chem. 48, 814817.

10) Nagai, T., Kobayashi, K., Harada, K., Iwagaki, S. and Sakai, T. (1979): Change in lipid composition in developing myocardial muscle. Jikeikai Med. J. 26, 201-207.

11) Peter, J.B. and Fiehn, W (1973) : Muscle lipids:Composition of muscle composed predominantly of one fibre type and of subcellular fractions. In : Basic Research in Myology. I. Ed. by B.A. Kakulas. Amsterdam, Excerpta Medica. 183-189.

12）佐藤恒久(1970)：ガマ骨格笳細胞膜の 2,3 の 醇素活性之その局在性汇関する考察. 11本作理 学雑誌 32 \% $317-328$.

13) Stein, O. and Stein, Y. (1968) : Lipid synthesis, intracellular transport and storage. III. Electron microscopic radioautographic study of the rat heart perfused with tritiated oleic acid. J. Cell. Biol. 36, 63-77.

14) Stoffel, W., Chu, F. and Ahrens, E.H.Jr. (1959): Analysis of long-chain fatty acid by gas-liquid chromatography. Analyt. Chem. 31, 307-308.

15) Tan, M.H., Sata, T. and Havel, R.J. (1977): The significance of lipoprotein lipase in rat skeletal muscles. J. Lipid Res. 18, 363370 . 